\title{
Theorising the Concept of Organisational Artefacts: How It Enhances the Development of Corporate/Organisational Identity
}

\author{
Olusoji James George \\ Department of Business Administration, University of Lagos, Lagos State, Nigeria \\ E-mail: eniolasojigeorge2@yahoo.com \\ Oluwakemi Owoyemi (Corresponding author) \\ Department of Industrial Relations \& Personnel Management, University of Lagos, Lagos State, Nigeria \\ E-mail: oowoyemi@unilag.edu \\ Uchechi Onakala \\ Department of Business Administration, University of Lagos, Lagos State, Nigeria \\ E-mail: ucheonokala@yahoo.com
}

Received: April 23, 2012

Accepted: May 2, 2012 Published: July 15, 2012

doi:10.5430/ijba.v3n4p37

URL: http://dx.doi.org/10.5430/ijba.v3n4p37

\begin{abstract}
Organisational artefacts are materials, buildings, symbols, names, images, logos, catchwords that make sense to all the stakeholders of an organisation; they therefore have meanings and do not just exist. Artefacts demonstrate the culture, norms and values of those who are in the organisation as well as all its stakeholders. In a nutshell it is a medium of communication within the members of the organisation and those outside the organisation; it makes enormous statements. This paper employing the descriptive/historical approach will examine the impacts of organisational artefacts on business organisations including how it helps in the development of a corporate identity in the organisations. This is more so as an organisation's identity -expressed partly through organisational artefacts- goes directly to the heart of the existence of the organisation. The study concludes that directly and indirectly, knowingly and unknowingly, organisational artefacts enhance the development of corporate identity.
\end{abstract}

Keywords: Organisations, Organisational culture, National culture, Artefacts, Corporate identity

\section{Introduction}

There is recently a shift on the emphasis on corporate branding from line branding as there is a need to better appreciate the role and the importance of organisational artefacts in the development of corporate identity (Balmer, 1995; Mitchell, 1997). Corporate identities therefore refer to the 'engaging and influential conceptualizations of the organisation, which are relatively shared by members and/or upheld by its leaders, and often emphasized in formal corporate statements (mission, vision etc) and expressions (logos, buildings, symbols, etc)' (Lerpold et al., 2007:2). Our focus in this study will be the latter part of the definition, 'expressions (logos, buildings, symbols) and the impact of these expressions' on the corporate identities. These expressions or organisational artefacts help in answering the following questions: 'Who are we?'; 'What kind of organisation is this?'; 'What makes us different from, or similar to, other organisations?' Who do we compare with? And 'Who is our benchmark or role model?'

Lerpold et al. (2007:5) perceive organisational/corporate identity as the 'result of the interplay of three closely connected and sometimes overlapping elements: formal claims (i.e., 'what we say we are as an organisation'); members' beliefs and understandings about what is central, enduring, and distinctive about their organisation (i.e., 'what we think we are as an organisation'); and the managers' aspirations about it (i.e. , 'what we would like our organization to be'), or what is sometimes referred to as desired identity'.

These three elements: identity claims, identity beliefs and identity aspirations can be illustrated or made manifest through organisational artefacts like uniforms, logos, visuals, buildings etc (Lerpold, et al., 2007: 174-175 \& 197; Olins, 
1989; Pratt and Rafaeli, 1997; Ravasi and Schultz, 2006). These expressions and manifestations of organisational/corporate identity are usually in form of objects and symbols. A symbol according to Saussure (1996) is something that represents or suggests something else through associations, norms or conventions. The meaning of a symbol is usually rooted in its cultural significance (Thompson, et al, 1996); the communication of which is interpreted thorough the eventual production of symbols that make the world meaningful (Putman, et al., 1996).

Culture has been variously defined as the way of life of a group of people (Akporherhe, 2002); Becker (1986:13) suggests that culture 'explains how people act in concert when they do share understanding.' quoting Taylor (1921), Olurode (1994) suggests that culture is that whole, which includes knowledge, belief, art, moral, law, custom and other capabilities and habits acquired by man as a member of the society. Geertz (1973a) suggests that culture is the entire way of life of a people, including their technology and material artefacts; Hofstede and Hofstede (2005:3) simply define culture as 'software of the mind'. From the above definitions and explanations of 'culture', it is obvious that wherever a group of people come together there are bond to be some norms, values, conventions that will bind them together part of which will manifest through their artefacts, this is referred to as organisational culture.

Unfortunately, people are often not aware of the model represented by their organisational culture until it is questioned or until they come into contact with a new culture or until it is presented and explained (Snopko,2011). In the view of May (2001), culture can be infused throughout the organisation by expressing it in the artefacts of the organisation. Artefacts can be considered as mental models which mediate activity (Milne, 2010).

Organisational or corporate culture has attracted much attention in both management and management practices literature in recent times (Deal and Kennedy, 1988; Denison, 1990; Peters and Waterman, 1982; Lau and Ngo, 1996; Mintzberg, 1989). It has also been variously defined as the history of an organisation or what allows employees to understand their workplace, it also makes the employees to make sense of work activities and to relate them to daily events (Porter, 1990). Williams et al (1993) define it as the beliefs, attitudes and values that are commonly-held and that are relatively stable within an organisation. Hall (1995:25) sees it simply as 'the way we do things around here'; which is 'embodied in symbols, rituals and hero's which are reflected in organisational communications, manners, dress codes, social rules and norms, and role models' (Mwaura et al, 1998). The functions of organisational culture include passing on of knowledge, handling strong emotions, uniting and providing meanings; it also forms one of the basis for competitive advantage (Deal and Kennedy, 1988; Randlesome and Brierly, 1990). It helps in determining the effectiveness of a company (Denison, 1990); it is important in developing high performance amongst staff (O' Reilly, 1989) and also helps in increasing the loyalty of staff to the organisation (Porter, 1990).

From the above discussions it can be inferred that organisational artefacts can help in communication within an organisation as well as be a shared bond that ties members of the organisation together; this may be deliberately or unknowingly created. For example an organisation that adopted a lion as its logo is talking of boldness (in terms of competition), and leadership (probably a market leader). Members of the organisation will have to perceive the organisation as a lion and consciously or unconsciously behave like lions.

\section{Conceptual Background}

The last two or three decades have witnessed an increase of interest in the study of corporate/organisational identity by two distinct, but inextricably linked academic disciplines: the marketing discipline which refers to it as 'corporate identity' while the organisational behaviour discipline refers to it as 'organisational identity' (Balmer and Wilson, 1993). Researchers from the marketing and general management will want to answer the following questions: What is corporate identity? What is the purpose of corporate identity management? And what is an organisation? (Balmer, 1995; Balmer and Wilson, 1998)

Corporate identity according to van Riel and Balmer (1997) (while quoting the International Corporate Identity Group's statement) is interpreted as an organisation's ethos, aims and values that create a sense of individuality which differentiate a brand from another brand. De Chernatony (1999) building on Kapferer's (1997) brand-based view of identity, simply defines it as the process of narrowing the gap between a brand's identity and its reputation. De Chernatony ( 1999) further suggested that brand identity consists of six components: vision and culture which drives the brand's desired for which the organisation is known which then drive the brand's desired positioning, personality and subsequent relationships all of which are then presented to reflect stakeholders' actual and inspirational self-images

Balmer and Stotvig (1997) posit that securing a competitive advantage is the main objective of corporate identity; it is assumed that once an organisation is able to put in place an effective management of its identity, the organisation will in due cause acquire a positive and favourable corporate image and reputation and the end result will be that the major stakeholders will view the organisation favourably and positively. Scholars in the organisational behaviour discipline 
view organisational identity as the way the employees identify with the organisation (Hatch and Schultz, 1997). Albert and Whetten (1995) view organisational identity as the elements within an organisation that are central, enduring and distinctive; this to a large extent will help in answering questions such as: 'to what extent do employees identify with the organisation? And, 'What do employees identify within the organisation?

Balmer and Wilson (1998:4) suggest that despite 'the heightened interest in corporate identity by academics and managers, there is still confusion and ambiguity as to the nature of corporate identity'. Balmer, (1997) identified six reasons why the 'confusion and ambiguity' still exist; they are (1) confusion caused by the terminology (2) influence of fashion which keeps changing everyday (3) the association with graphic design (4) the dearth of academic empirical research (5) the inappropriateness of the positivistic research paradigm for undertaking research in corporate identity during its early stage of development and (6) the weaknesses in available models of corporate image and identity.

This paper intends to examine how organisational artefacts can be used to develop both organisational identity and corporate identity so that both disciplines and group of scholars can have a common ground from which to learn from (Hatch and Schultz, 1997). This is beacuse according to Balmer and Wilson (1993:4) 'marketers and organisational behaviourists have much to learn from each other's literatures'. Moreover, Balmer (1995) and Ramanantsoa (1989) argue that more scholars have started clinging to the fact that corporate identity simply refers to an organisation's unique characteristics that are rooted in the behaviour of employees. This probably was why several scholars (Balmer, 1995; Hatch and Schultz, 1997; van Riel and Balmer, 1997) argued that corporate identity does not sit firmly in one area of management but belongs to several disciplines and that this is why scholars (van Riel and Balmer, 1997) recommended that multidisciplinary approach should always be adopted while discussing corporate identity.

Corporate culture which usually manifests through organisational artefacts has always been included in the conceptual models of corporate identity and corporate image formation; this explains why contemporary corporate identity consultancies have stressed the importance of both national culture and corporate culture while attempting to analyse or design corporate identity (Abratt, 1989; Balmer, 1997; Dowling, 1994).

Downey (1986/1987) (quoted in Balmer and Wilson, 1998:7) perceives corporate identity as the source of corporate culture; he (1986/1987) further suggested that corporate/organisational culture which can been be depicted as a company's shared values, beliefs and behaviour actually flows from and is the consequence of corporate identity. Olins (1978) sees the concept of corporate identity as the concept of the corporate personality. Balmer and Wilkinson (1991) suggest that corporate identity refers to the values that are held in high esteem by employees within an organisation. Some scholars such as Abratt (1989); Birkight and Stadler (1986); Lux (1986) and Olins, (1989) have all argued that corporate personality is at the hub of an organisation's corporate identity. One of the major features of the corporate identity literature is the fact that organisations have a single company culture; which manifests partly through organisational artefacts (Balmer and Wilson, 1989).

Organisational behaviourists including Scott (1987) suggested that organisations are much more concerned about corporate culture as it helps in sustaining commitment of employees towards the good of the whole organisation. It is assumed that individual employee who has legitimately internalised the norms, values and conventions (usually expressed through organisational artefacts) of the organisation will engage in co-operative and spontaneous behaviour in his/her service to the organisation (Balmer and Wilson, 1998).

Martin and Meyerson (1988) suggest three major perspectives in corporate culture as: Integration, differentiation and fragmentation. Integration perspective is a situation where there is an organisation-wide consensus and consistency; this is a strong and desirable corporate culture. The values, norms and conventions (which mainly manifests through organisational artefacts) are consistent with formal practices which are consistent with informal beliefs, norms and attitudes. Organisational members share the same values which help in promoting a shared sense of loyalty which enhances commitment to the organisation (Barley, 1983; Deal and Kennedy, 1982; Peter and Waterman, 1982).

Differentiation perspective: Consensus does not form the corporate culture but only exists in the sub-culture; it (consensus) is therefore not organisational-wide. The sub-culture is related to different jobs, different levels of organisational status, gender and class; there exists therefore a mixture of sub-cultural differences within the same organisation (Van Maanen, 1991). Fragmentation perspective: Ambiguity is viewed as the norm while consensus and dimension only co-exist in a constantly changing pattern which is influenced by events and specific areas of decision-making. Consensus fails to unite on an organisation-wide basis and not even on sub-cultural based; only in brief and issue- specific ways (Frost et al, 1991). We are going to argue in this paper that it is cheaper and more effective to use organisational artefacts to build a solid corporate/organisational culture which will help in building an enduring organisational. 


\section{Methodology and Method}

\subsection{Historical /Descriptive Research Method/Approach}

This study being historical and descriptive relied on the secondary sources. Secondary data are data collected and recorded by someone else prior to and for purposes other than the current needs of the researcher (Harris, 2001). Secondary data is usually historical and already collected data that does not necessitate access to respondents or subjects (Ember and Levinson, 1991). The major advantage of this source of data collection is the fact that it is less expensive than the primary source of data collection (Zikmund, 1984).

If one also looks at the fact that nowhere in science do we start from scratch, it is therefore a good source of proceeding with a research even if one will still have to go back to the primary source; there is something handy one can use as a starting point (Kaplan, 1964). One can also build on the researches already conducted by other people using the secondary source as the basis of judgement. There are some instances where only the secondary sources can be used and there was no way of considering primary source at all; for example a researcher conducting researches into events that happened a long time ago has no other choice than to depend on secondary source (Harris, 1991).

The four main purposes of secondary sources methodology are: to describe, to explain, to validate findings and to infer from all the findings having been validated to be true (Black and Champion, 1976). Description emerges following the creative exploration, and helps to arrange the findings in an order that will help to be fit for explanations and these explanations can then be tested to validate the variables being studied and with the aid of description, knowledge is illuminated and facts that were ignored can now be brought to light and better understood (Whiting, 1964). This method also helps in describing natural and man-made phenomena that will be very useful to other researchers and policymakers while prediction is also made easier at least to some extent (Borg and Gall, 1989).

\section{Discussions}

Maier (1967) suggested that many organisational problems could be linked to inadequate communication between superiors and their subordinates, whose task was to implement their decisions. The issue of lack of clarity of communications in organisations between management and workers, between managers and junior workers, between workers and workers as well as communications between the organisations and their customers along with other stakeholders cannot be taken for granted, therefore all efforts must be put on board to safe the situation. Organisational artefacts as mentioned earlier can aid effective communication in the organisation and members of the organisation are able to communicate informally and act in a more coherent manner which on the long run will likely enhance the likelihood of their activities as well as support the desired identity. This is could be done through the acceptance of organisational artefacts by all members of the organisation which could be a reminder of the values, norms and conventions of the organisation as well as a socialisation instrument which enhances the organisation's identity.

According to Freeman and Liedtka (1997) the role of employees is now changing as they can no longer be considered under the category 'firm'; they are now to be considered as corporate 'ambassadors' (Hemsley, 1998) of their various organisations. Employees are also the interface between the corporate internal and external environments which invariably have a powerful impact on consumers' perception of both the brand and the organisation as a whole (Schneider and Bowen, 1985; Balmer and Wilkinson, 1991). With organisational artefacts well in place employees can identify with them, and the goals of the organisation will be clearer to all the stakeholders which is likely to increase the loyalty and the commitment of the corporate 'ambassadors' to the advantage of the organisation as a whole.

\section{Conclusion}

As discussed earlier, organisational artefacts are very crucial to the effective internalisation of corporate/organisational culture while corporate/organisational identity is enhanced by corporate/organisation culture. Hofstede and Hofstede (2005:3) define national culture simply as the 'software of the mind'. It is therefore important, cheaper and more effective for organisations to invest on organisational artefacts in order to imprint the organisational culture in the 'minds' of their workers which will enhance their commitment and probably increase their productivity. Also as visuals last longer in the minds of people, organisational artefacts will help in reinforcing the values, norms and conventions of the organisation. As mentioned earlier, it is also cheaper and more effective especially when compared with the organisations of conferences, seminars and retreats in order to help in imprinting the values, norms and conventions of the organisation on the minds of its employees and other stakeholders.

\section{References}

Abratt, R. (1989). A New approach to the Corporate Image Management Process. Journal of Marketing Management, 5(1), 63-76. http://dx.doi.org/10.1080/0267257X 
Akporherhe, F. (2002). The Challenge of English and other foreign languages on Nigerian culture. Journal of Nigerian Languages and Culture, 3, 29-33.

Albert, S., \& Whetten, D.A. (1985). Organisational Identity. In Cummings, L. L. and Staw, B.M. (Eds.), Research in Organisational Behaviour, 7, 263-295.

Balmer, J.M.T. (1995). Corporate Branding and Connoisseurship. Journal of General Management, 21(1), 24-46.

Balmer, J.M.T. (1997). Corporate Identity: past, present and future. Working Paper 97/4. Department of Marketing, University of Strathclyde, Glasgow.

Balmer, J.M.T., \& Stovig, S. (1997). Corporate identity and private banking: a review and case study. The International Journal of Bank Marketing, 15(4\&5):169-184. http://dx.doi.org/10.1108/02652329710175370

Balmer, J.M.T., \& Wilkinson, A. (1991). Building Societies: Change Strategy and Corporate Identity. Journal of General Management, 17(2), 20-33.

Balmer, J.M.T., \& Wilson, A. (1998). Corporate Identity and the Myth of the Single Company Culture. Working Paper (1998/2) of the Department of Marketing University of Strathclyde, Glasgow, UK.

Barley, S. R. (1983). Semiotics and the Study of Occupational and Organisational Cultures. Administrative Science Quarterly, 28(3), 293-413. http://dx.doi.org/10.2307/2392249

Becker, H. S. (1986). Doing Things Together: Selected Paper. Evanston 111: Northwestern University Press.

Bernstein, D. (1986). Company Image and Reality: A Critique of Corporate Communications. England, UK: Hotl Reinhart and Winstone, Eastbourne.

Birkight, K., \& Stadler, M. M. (1995). Corporate Identity als unternehmerische Aufgabe. In Birkight, K. Stadler, M. M \& Funck, R. (Eds.), Corporate Identity, Grundlagen, Funktionem, Fallbeispiell, ( $\left.8^{\text {th }} \mathrm{ed}\right)$. Verlag, Mordern Industrie, Lansberg/Lech.

Black, J. A., \& Champion, D. J. (1976). Methods and Issues in Social Research. UK: John Wiley \& Sons.

Borg, W. R., Gall, M. D. (1989). Educational Research. New York: Longman.

Bowles, S., \& Gintis, H. (1990). Contested Exchange: New Microfoundations for the Political Economy of Capitalism. Politics and Society, 18(1), 165-222. http://dx.doi.org/10.1177/003232929001800202

Chajet, C., \& Shachtman, T. (1993). Image by Design. Massachusetts: Addison Wesley.

Cowtow, C. J. (1998). The Use of Secondary Data in Business Ethics. Journal of Business Ethics, 17(4), 423-434. http://dx.doi.org/10.1023/A:1005730825103

De Chernatony, L. (1999). Brand management through narrowing the gap between brand identity and brand reputation. Journal of Marketing Management, 15(1-3), 157-79. http://dx.doi.org/10.1362/026725799784870432

Deal, T., \& Kennedy, A. (1988). Corporate Cultures: The Rites and Rituals of Corporate Life. London: Penguin Books.

Deal, T.E., \& Kennedy, A. A. (1982). Corporate Cultures. USA: Addison-Wesley.

Denison, D. R. (1990). Corporate Culture and Organisational Effectiveness. York, NY: John Wiley.

Dowling, G. R. (1994). Corporate Reputations: strategies for Developing The Corporate Brand. London: Kogan Page.

Downey, J. M. (1986/1987). The Relationship Between Corporate Culture and Corporate Identity. Public Relations Quarterly, 7-12.

Ember, C. R., \& Levinson, D. (1991). The Substantive Contributions of Worldwide Cross-Cultural Studies Using Secondary Data. Behavior Science Research, 25(1-4), 79-140. http://dx.doi.org/10.1177/106939719102500105

Freeman, E., \& Liedtka, J. (1997). Stakeholder capitalism and the value chain. European Management Journal, 15(3), 286-96. http://dx.doi.org/10.1016/S0263-2373(97)00008-X

Frost, P. J., Moore, L. F. Louis, M.R., \& Craig, C. C. (1991). Reframing Organisational Culture. USA: Newbury Park, California.

Geertz, C. (1973a). The Interpretation of Cultures. New York, NY: Basic Books, Inc., Publishers.

Hall, W. (1995). Managing Cultures: Making Strategic Relationships Work. London: John Wiley \& Sons.

Harris, H. (2001). Content Analysis of Secondary Data: A Study of Courage in Managerial Decision Making. Journal of Business Ethics, 34(3-4), 191-208. http://dx.doi.org/10.1023/A:1012534014727 
Harris, J. R., \& Todaro, M., P. (1970). Migration, Unemployment and Development: A Two Sector Analysis. The American Economic Review, 6(1), 126-142. http://dx.doi.org/10.2307/1807860

Hatch, M., \& Schultz, M. (1997). Relations between Organisational Culture, Identity and Image. European Journal of Marketing, 31(5\&6), 356-365. http://dx.doi.org/10.1108/eb060636

Hemsley, S. (1998). Internal affairs. Marketing Week, April 2, 49-50, 53.

Hofsted, G., \& Hofstede, G.J. (2005). Cultures and Organizations, Software of the Mind: Intercultural Cooperation and Its Importance for Survival. New York, NY: McGraw-Hill.

Jenkins, N. (1991). The Business of Image. London: Kogan Page.

Kapferer, J. N. (1997). Strategic Brand Management. Creating and Sustaining Brand Equity Long Term (2nd ed.). London: Kogan Page.

Kaplan, A. (1964). The Conduct of Inquiry. San Francisco: Chandler.

Knox, G.A. (1986). Estuarine Ecosystems: A Systems Approach. Michigan: CRC Press.

Lau, C. M., \& Ngo, H.Y. (1996). One Country, many Cultures: Organisational Cultures of Different Country Origins. International Business Review, 5(5), 469-486. http://dx.doi.org/10.1016/0969-5931(96)00022-4

Lerpool, L., Ravasi, D. van Rekom, J., \& Soenen, G. (2007). Organisational Identity in Practice. London and New York: Rouledge (Taylor \& Francis Group).

Lux, P.G.C. (1986). Zur Durchfuhrung von Corporate Identity Programme, In Birkght, K. and stadler, M. (1986):515-537and in Van Riel, C.B.M. (1995). Principles of Corporate Communication. London: Prentice Hall.

Maier, N.R.F. (1967). Assets and liabilities in group problem solving. Psychological Review, 74(4), 239-49. http://dx.doi.org/10.1037/h0024737

Martin, J., \& Meyerson, D. (1988). Organisational Culture and Denial, Channeling and Ecknowledgement of Ambiguity. In L.R. Pondy, R.J. Boland, Jr.. \& H. Thomas (Eds.), Managing Ambiguity and Change. New York, NY: John Wiley \& Sons.

May, D. (2011). Building the Cultural Artifacts of the Organisation. [Online] Available: http://2001_May_CulturalAtifacts (June 11, 2012)

Milne, P. (2010). Musings on Quality and Organisational Culture in Primary Care'. Quality in Primary Care, 18, 157-60.

Mintzberg, H. (1989). Mintzberg on Management: Inside Our Strange World of Organisations. New York: NY.Free Press.

Mitchell, A. (1997). Brand Strategies in the Information Age. Financial Times Report, London.

O’ Reilly, C.A. (1989). Winning Through Innovation. In Tushman, M. (Ed.), Readings in the Management of Innovation. Pitman, Boston, M.A.

Olins, W. (1978). Corporate Identity: The Myth and the Reality. In J. M. T. Balmer and S. Greyser (Eds.), Revealing the Corporation. Perspectives on Identity, Image, Reputation, Corporate Branding and Corporate-level Marketing (p. 53-65). London: Routledge.

Olins, W. (1989). Corporate Identity: Making Business Strategy Visible through Design. Boston, Mass: Harvard Business School Press.

Olurode, Lai. (1994). Nigerian Heritage. Lagos: Rebonik Publications Ltd.

Peter, T., \& Waterman, D. R. (1982). In Search of Excellence: Lessons From America's Best Run Companies. London and New York: Harper Collins.

Porter, M. E. (1990). The Competitive Advantage of Nations. London: Macmillan.

Pratt, M. G., \& Rafaeli, A. (1997). Organisational Dress as a Symbol of Multilayered Social Identity. Academy of Management Journal, 40(4), 862-899. http://dx.doi.org/10.2307/256951

Putman, L. L., Philips, N., \& Chapman, P. (1996). Metaphors of Comminication and Organisation. In S.R. Clegg, S. Handy and W.R. Nord (Eds), Handbook of Organisational Studies. UK: Sage Publications.

Ramanantsoa, B. (1988). Strategor, Strategie, structure, Decision Identitie. Politique Generale d'enterprise. Paris: InterEditions.. 
Ravasi, D., \& Schultz, M. (2006). Responding to Organisational Identity Threats: Exploring the Role of Organisational Culture. Academy of Management Journal, 49(3), 433-458. http://dx.doi.org/10.2307/20159775

Saussure, F. de. (1966). Course in General Linguistic, translated by W. Baskin. New York: McGraw-Hill.

Schein, E. H. (1991). Organisational Culture and Leadership (2 ${ }^{\text {nd }}$ edition). San Francisco: Jossey Bass.

Schneider, B., \& Bowen, D. (1985). Employee and customer perceptions of service in banks: replication and extension. Journal of Applied Psychology, 70(3), 423-33. http://dx.doi.org/10.1037/0021-9010.70.3.423

Scott, W.R. (1987). Organisations: Rational, Natural and Open Systems. Prentice Hall: New Jersey, USA.

Snopko, J. (2011). Organisational Culture of Municipal Offices in Poland in the Light of Empirical Research Culture-related Conditions for Organisational Changes. Contemporary Management Quarterly, 3, 48.

Taylor, G. (1921). The Evolution of Race, Culture, and Language. Geographical Review, 11(1), 54-119. http://dx.doi.org/10.2307/207857

Thompson, C.J., Pollio, H.R., \& Locander, W.B. (1994). The Spoken and Unspoken, A Hemeneutic Approach to Understanding the Cultural Viewpoints that Underlie Consumer Research. Journal of Consumer Research, 21, 432-452. http://dx.doi.org/10.1086/209409

Van Maanen, J. (1991). The Smile Factory: work at Disneyland. In P. J. Frost et al. (eds.), Reframing Organisational Culture. California: Sage.

Van Reil, C. B. M. (1995). Principles of Corporate Communication. London: Prentice Hall,

Van Reil, C.B.M., \& Balmer, J.M.T. (1997). Corporate Identity: the concept, its measurement and management. European Journal of Marketing, 31(5\&6), 340-355. http://dx.doi.org/10.1108/eb060635

Van Riel, C.B.M. (1995). Principles of Corporate Communication. London: Prentice Hall.

Van Riel, C.B.M., \& Balmer, J. (1997). Corporate Identity: the concept, its measurement and management. European Journal of Marketing, 31(5/6):340-355. http://dx.doi.org/10.1108/eb060635

Whitfield, K., \& Strauss, G. (1998). Researching the World of Work: Strategies and Methods in Studying Industrial Relations. New York, NY: ILR Press.

Whiting, R. J. (1964). Historical Search in Human Relations. Academy of Management Journal, 7(1), 45-53. http://dx.doi.org/10.2307/255233

Zikmund, Z. (1984). Symmetry of domain pairs and domain twins. Journal of Physics, 34(9), 932-949. http://dx.doi.org/10.1007/BF01589823 